\title{
PERFORMANCE OF FRENCH BEAN (Phaseolus vulgaris L.) GENOTYPES IN SYLHET REGION OF BANGLADESH
}

\author{
M. I. Nazrul* and M. R. Shaheb \\ On-Farm Research Division (OFRD), Bangladesh Agricultural Research Institute), Sylhet, Bangladesh. \\ *Corresponding authors: mi_nazrul@yahoo.com
}

Keywords: Pulse crop. Hill agriculture, Seed yield,

\begin{abstract}
An experiment was conducted at farming system research and development (FSRD) site, Jalalpur and multi location testing (MLT) sites, Zokigonj and Moulvibazar during 2013-2015 to evaluate the suitable varieties (genotypes) of French bean for maximize the seed yield of the farmers. The experimental design was a randomized complete block (RCB) with 6 dispersed replications. Eight bush bean genotypes were tested of which 3 were developed by BARI (var. BARI Jharsheem-1, BARI Jharsheem-2, BARI Jharsheem-3), five local accessions: Local-1(black), Local-2 (white colour with chocolate spot at hylum), Local-3 (coffee colour), Local-4 (coffee colour with few chocolate spots) and Local-5 (black with chocolate colour spots). The seed yields were varied significantly among the genotypes. All the local French bean lines performed better and produced higher seed yields compared to BARI developed varieties. The maximum seed yields $2.66,3.48$ and $2.05 \mathrm{t} \mathrm{ha}^{-1}$ was produced by Local-4 and Local-5 at Jalalpur, Zakigonj and Moulvibazer, respectively. So, Local-4 and Local- 5 variety as the most promising one due their relatively good plant vigor and high seed yield potentiality.
\end{abstract}

\section{Introduction}

French bean (Phaseolus vulgarris L.) is commonly known as Forashi sheem or Jhar sheem in Bengali (Roy et al., 2006), belongs to the family Fabaceae is an annual, diploid $(2 n=2 x=22)$ species (Galvan et al., 2003). It is a dual purpose crop grown as pulse and also consumed as immature tender fruits. It is an important legume, grown in the areas of Jessore, Rangpur, Comilla, Chittagong and Sylhet in Bangladesh. Its dry seed contains 21.1 per cent protein, 69.9 per cent carbohydrates, 1.7 per cent fat, $381 \mathrm{mg}$ calcium, $425 \mathrm{mg}$ phosphorous and $12.4 \mathrm{mg}$ iron per $100 \mathrm{~g}$ of edible part (Ali and Kushwaha, 1987). It is also reported that common bean is an important source of protein and calories in human diets (Smithson et al., 1993). French bean is becoming popular for its tender pods and shelled beans. Besides, it maintains soil fertility through biological nitrogen fixation in association with symbiotic Rhizobium prevalent in their root nodules. The suitable variety in appropriate soil is the two important factors for higher crop production (Dhanjal et al., 2001; Shivakumar et al., 1996; Singh et al., 1996). In Sylhet region, farmers are generally cultivating local French bean cultivars of different in colour, shape, size and also vary in taste. Some of these are high yielder, disease and drought resistant. Three varieties of French bean have been developed by Bangladesh Agricultural Research Institute (BARI), but inadequate information on their performance in Surma Kushiyara Floodplain soil under AEZ 20. As such, the present study was under taken to identify the varietal performance of the local accession as well as BARI developed varieties for Sylhet region.

\section{Materials and Method}


Nazrul et al.

An on-farm study was conducted on French bean in Sylhet and Moulvibazar districts during 2013-2014 \& 2014-2015 under agro ecological zone of AEZ 20 with the objectives were to find out the suitable variety of French bean in respect of seed yield and income of the farmers. The experiments were conducted at farming system research and development (FSRD) site, Jalalpur and multi location testing (MLT) sites, Zokigonj and Moulvibazar locations. The study area lays $24^{\circ} 70^{\prime} \mathrm{N}$ latitude and $91^{\circ} 67^{\prime} \mathrm{E}$ longitude under the Surma-Kusiyara Floodplains in Bangladesh on an altitude of 10 meters. The monthly temperature and rainfall for the experimental sites are indicated in figures $1 \mathrm{a}-1 \mathrm{~b}$ and $2 \mathrm{a}-2 \mathrm{~b}$. The climatic data of Moulvibazar and Sylhet districts showed that the average annual minimum temperature is 11.64 and $7.50^{\circ} \mathrm{C}$ and the average annual maximum temperature is 34.06 and $33.70^{\circ} \mathrm{C}$ and the annual average temperature nearly 18.62 and $25.25^{\circ} \mathrm{C}$, respectively. As indicated in Figure $2 a-2 b$, the rainfall of two different locations is uni-modal, usually occurring during April to October, and total annual rainfall reached to 2354 and 4700 $\mathrm{mm}$; whereas in December no rain at all except in the year of 2014 and lowest amount of rainfall occurs in January followed by February. However, in rest of the months total rainfall was ranged from $100 \mathrm{~mm}$ to just below $200 \mathrm{~mm}$. Rainfall increases gradually from the month of May and continued up to September.

\section{Descriptions of the Experimental Locations}

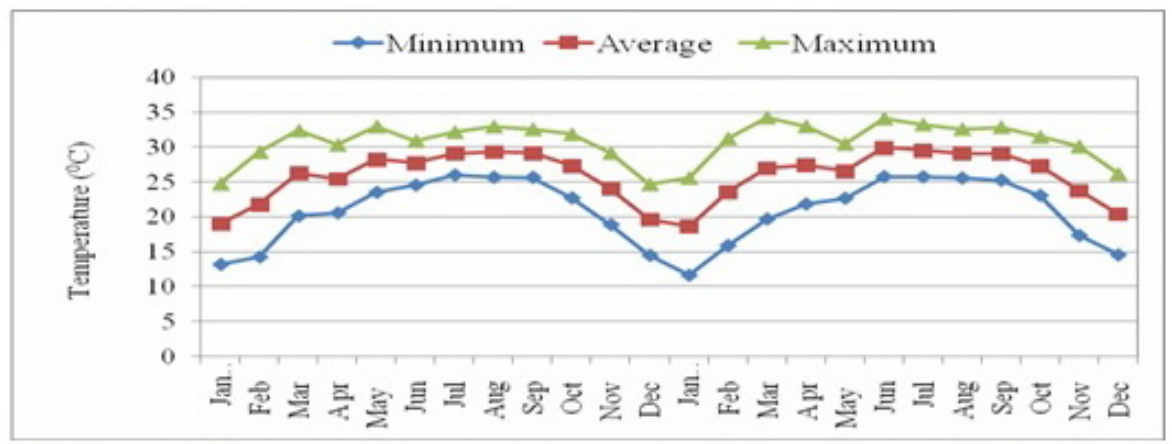

Fig. 1a. Minimum, Maximum and Mean Temperature $\left({ }^{\circ} \mathrm{C}\right)$ pattern in Sylhet of Bangladesh, during 2013-14.

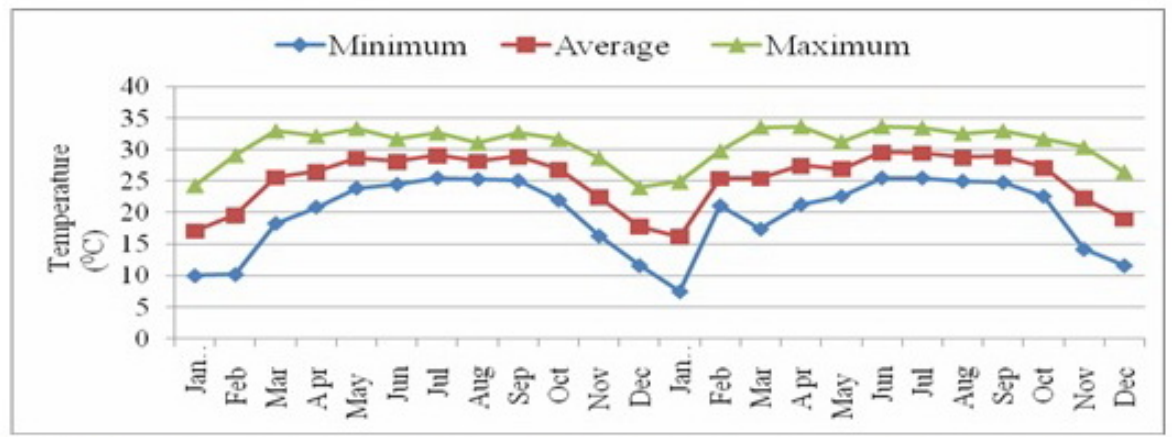

Fig. 1b. Minimum, Maximum and Mean Temperature $\left({ }^{\circ} \mathrm{C}\right)$ pattern in Moulvibazar of Bangladesh, during 2013-14.

Fig. 2a. Annual Rainfall (mm) pattern in Sylhet of Bangladesh, during 2013-14 


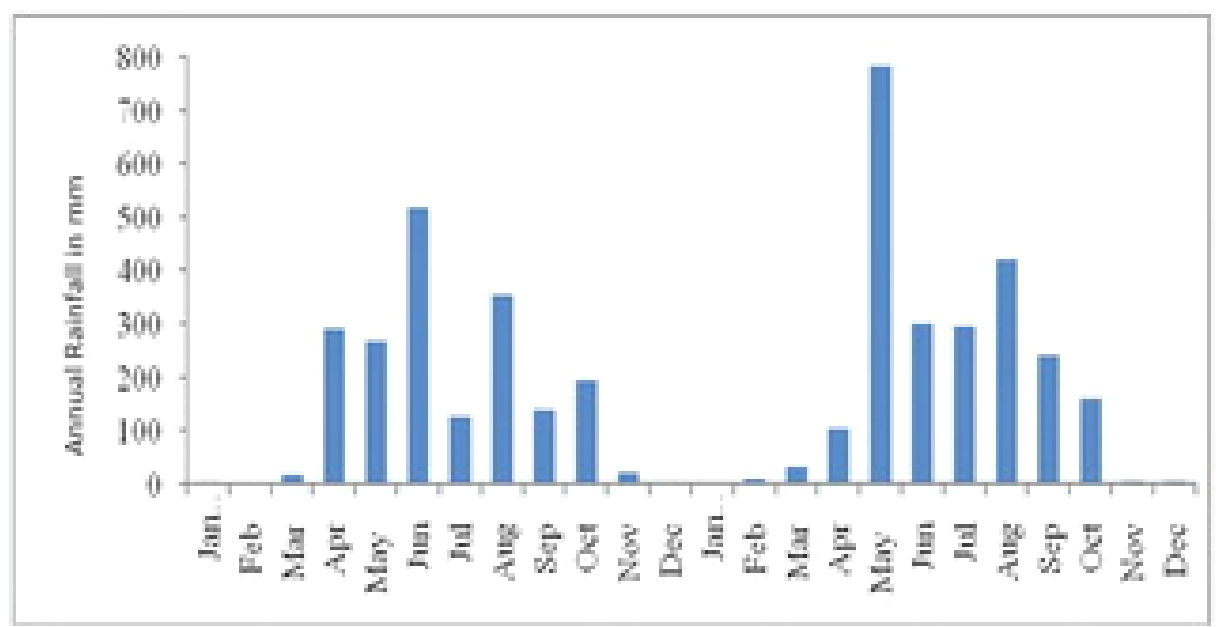

Fig. 2a. Annual Rainfall (mm) pattern in Sylhet of Bangladesh, during 2013-14

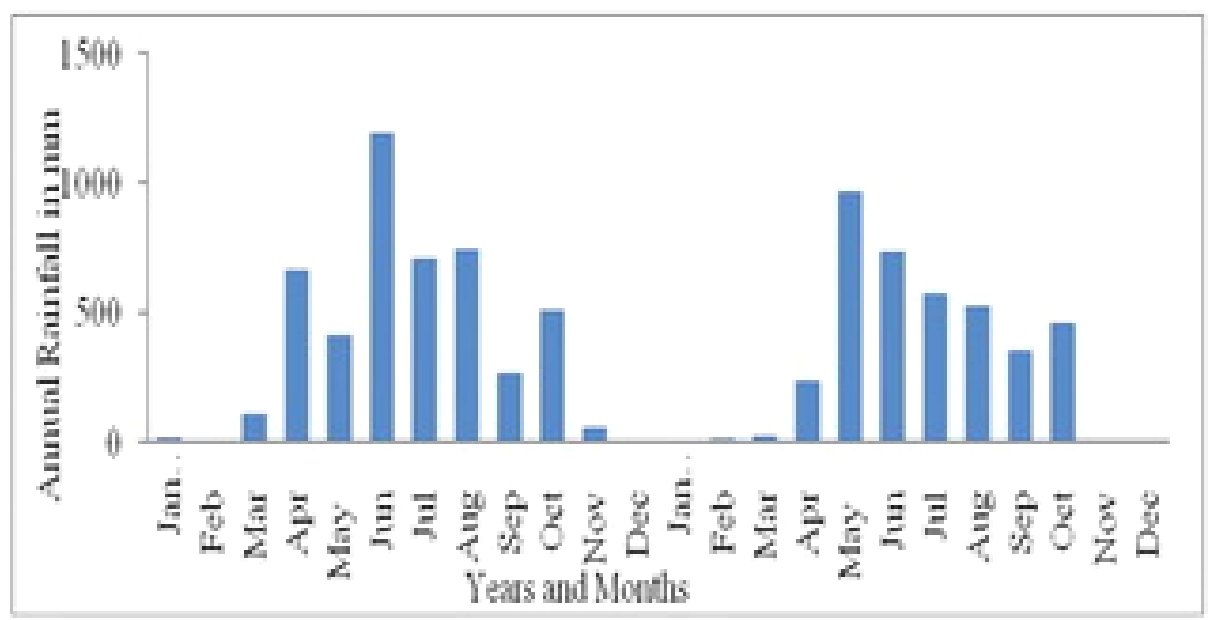

Fig. 2b. Annual Rainfall (mm) pattern in Moulvibazar of Bangladesh, during 2013-14

The experimental design was a randomized complete block (RCB) with 6 dispersed replications. Seeds were planted at $15 \mathrm{~cm}$ in row and $30 \mathrm{~cm}$ between rows with 2 seeds per hole. Eight French bean genotypes (Fig. 3) were tested of which 3 were developed by BARI (var. BARI Jharsheem-1, BARI Jharsheem-2, BARI Jharsheem-3), five local accessions Local-1(black), Local-2 (white colour with chocolate spot at hylum), Local-3 (coffee colour), Local-4 (coffee colour with few chocolate spot) and Local-5 (black with chocolate colour sport). Fertilizers were applied @ 91-21-31-7-1-0 Kg ha-1 of NPKSZnB in the form of Urea, TSP, MoP, Gypsum, Zinc sulphate and Boric acid, respectively. Cow dung was used as per $5 \mathrm{t} \mathrm{ha}^{-1}$ during final land preparation. Seeds of French bean were sown on 15-20 November and harvested at maturity on 25-28 February in each year. The trial was manually weeded at three weeks after sowing followed by irrigation, and other irrigations at six weeks after sowing and before harvest. The fungicides Bavistin and Tilt 250EC @ $0.5 \mathrm{ml} / \mathrm{L}$ of water were applied for controlling damping off and blight disease, respectively. Data on yield and yield 
Nazrul et al.

components were analyzed and mean values were separated by LSD test following Gomez and Gomez (1984).
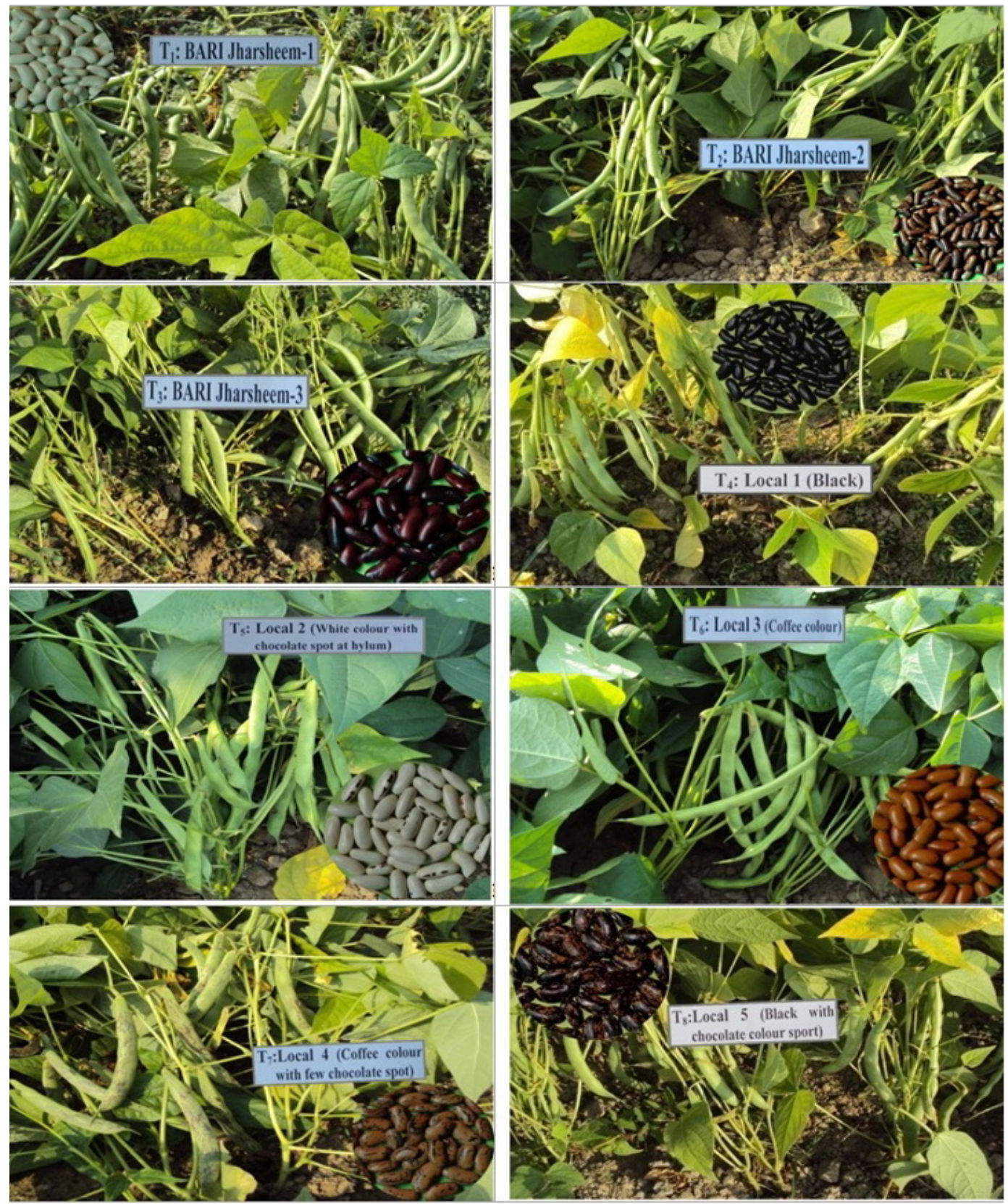

Fig. 3. $\mathrm{T}_{1}$ : $\mathrm{BARI}$ Jarsheem-1; $\mathrm{T}_{2}$ : $\mathrm{BARI}$ Jarsheem-2; $\mathrm{T}_{3}$ : BARI Jarsheem-3; $\mathrm{T}_{4}$ : Local-1 (black); $\mathrm{T}_{5}$ : Local-2 (white color with chocolate spots at hylum); $\mathrm{T}_{6}$ : Local-3 (coffee color); $\mathrm{T}_{7}$ : Local-4 (coffee color with few chocolate spots) and $\mathrm{T}_{8}$ : Local-5 (black with chocolate color spots) 
Performance of French Bean (Phaseolus vulgaris L.) Genotypes in Sylhet Region of Bangladesh

\section{Results and Discussions}

Results of pooled data from two different years of French bean varieties and lines at FSRD site, Jalalpur and MLT sites, Zokigonj and Moulvibazar area have been shown in Table 1, 2 and 3, respectively. Location wise detail descriptions were given below:

\section{Location: FSRD site, Jalalpur}

It was observed that the plant height was significantly influenced by the French bean genotypes where the highest plant height of French bean was recorded in Local-5 (42.59 $\mathrm{cm})$ while the lowest plant height $(37.29 \mathrm{~cm})$ in Local-1. The maximum pods per plant were obtained in BARI Jharsheem-2 (13.62) that was statistically similar with that of BARI Jharsheem-3 (12.99) while lowest pods (7.84) per plant in line Local-4. But, in case of pod length, the maximum was found in line Local-3 $(14.01 \mathrm{~cm})$ followed by Local-5 $(14.01 \mathrm{~cm})$. These findings corroborate with Mozumder et al., 1996 and they found wide variation (8.9 to $17.7 \mathrm{~cm}$ ) in pod length of bush bean genotypes. It is also remarked that all the local French bean lines provided the highest length of pod than that of BARI developed varieties. Among the genotypes seeds per pod were the maximum in BARI Jharsheem-1 (5.11) that was statistically followed by BARI Jharsheem-3 (4.95), and the lowest in line Local-2 (3.95). In case of 100-seed weight, line Local-4 was produced the maximum value $(86.42 \mathrm{~g})$ that was statistically followed by lines Local-5 $(81.96 \mathrm{~g})$ and Local-3 $(80.79 \mathrm{~g})$. The lowest 100 -seed weight was gained in all of BARI developed varieties. Genotypic variation in 100-seed weight was also observed by other researchers in French bean (Muthuramu et al., 2015; Singh et al. 2014; Mozumder et al., 1996) that also conformity with the present experimental findings. The French bean line Local-5 produced statistically higher seed yield (2.65 tha $\left.{ }^{-1}\right)$ while lowest seed yield (1.29 $\left.\mathrm{t} \mathrm{ha}^{-1}\right)$ was recorded in BARI Jharsheem-2 (Table 1). The local lines of French bean contributed higher seed yield compared to that of BARI developed varieties due to bigger size with higher 100- seeds weight in local lines.

Table 1. Yield contributing characters and seed yield of French bean at FSRD site, Jalalpur during 2013-15 (Pooled of 2 years).

\begin{tabular}{|c|c|c|c|c|c|c|}
\hline Treatment & $\begin{array}{c}\text { Plant } \\
\text { height } \\
(\mathrm{cm})\end{array}$ & $\begin{array}{c}\text { Pods } \\
\text { plant }^{-1} \\
\text { (nos.) }\end{array}$ & $\begin{array}{c}\text { Pod } \\
\text { length } \\
(\mathrm{cm})\end{array}$ & $\begin{array}{l}\text { Seeds } \\
\text { pod }^{-1} \\
\text { (nos.) }\end{array}$ & $\begin{array}{l}\text { 100- seed } \\
\text { weight }(\mathrm{g})\end{array}$ & $\begin{array}{c}\text { Seed } \\
\text { yield } \\
\left(\text { tha }^{-1}\right)\end{array}$ \\
\hline $\begin{array}{l}\text { BARI Jharsheem- } \\
1\end{array}$ & 41.55 & 11.09 & 12.88 & 5.11 & 41.475 & 1.43 \\
\hline $\begin{array}{l}\text { BARI Jharsheem- } \\
2\end{array}$ & 40.73 & 13.62 & 12.04 & 4.44 & 32.79 & 1.29 \\
\hline $\begin{array}{l}\text { BARI Jharsheem- } \\
3\end{array}$ & 41.71 & 12.99 & 12.13 & 4.95 & 43.12 & 1.55 \\
\hline Local-1 & 37.29 & 8.79 & 12.87 & 4.52 & 61.46 & 2.39 \\
\hline Local-2 & 42.86 & 10.17 & 13.47 & 3.95 & 79.09 & 2.22 \\
\hline Local-3 & 41.70 & 8.98 & 14.11 & 4.50 & 80.79 & 2.32 \\
\hline Local-4 & 41.21 & 7.84 & 13.43 & 4.36 & 86.42 & 2.66 \\
\hline Local-5 & 42.59 & 7.93 & 14.01 & 4.77 & 81.96 & 2.65 \\
\hline CV (\%) & 11.23 & 13.59 & 6.95 & 10.03 & 16.62 & 18.48 \\
\hline $\operatorname{LSD}_{(0.05)}$ & 4.58 & 2.61 & 1.23 & 0.59 & 18.11 & 0.60 \\
\hline
\end{tabular}

Location: MLT site, Zokigonj 
Nazrul et al.

The yield and yield contributing characters of French bean studied at Zokigonj were furnished in the Table 2, where plant height was found non-significant, but the higher plant height was recorded in BARI Jharsheem-3 $(46.19 \mathrm{~cm})$ while the lowest value $(41.47 \mathrm{~cm})$ in Local-1. The maximum number of pods per plant of French bean was recorded in the line Local-3 (12.74) and the lowest value (9.53) in Local-4. These results are in agreements with the findings of Singh and co-workers (Singh et al., 1996), who reported that the number of pods per plant in French bean genotypes varied from 10 to 12 . Though the almost similar pod length was observed in all the tested genotypes but sharp difference was found between BARI developed varieties and local lines. Higher pod lengths were found in local lines which may be contributed to gain maximum seed yield of French bean. The seeds per pod are an important attributes of seed yield. Number of seeds per pod varied significantly depending on the genotypes. The maximum number of seeds per pod was obtained for BARI bush bean -1 (5.57). Noor et al. (2014) studied nine French bean genotypes, of which BARI bush bean -1 (5.80) contributed the highest number of seeds per pod. Though, BARI developed French bean varieties have some more number of seeds per pod, but the yield was lower which might be due to the smaller size of seeds. In case of 100 - seeds weight, the line Local-5 gave the maximum weight $(81.45 \mathrm{~g})$ that was statistically followed by the lines Local$3(80.82 \mathrm{~g})$ and Local-4 $(79.00 \mathrm{~g})$. The lowest value $(38.67 \mathrm{~g})$ of 100 - seed weight was recorded in BARI Jharsheem-1. The genotypic differences on 100-seed weight in French bean have also been reported by Das et al. (2014). The highest seed yield of French bean was found in the line Local-5 (3.48 $\left.\mathrm{t} \mathrm{ha}^{-1}\right)$ that was statistically similar with that of all other local lines except the Local-1. However, the lowest seed yield (1.58 $\left.\mathrm{t} \mathrm{ha}^{-1}\right)$ was recorded in BARI Jharsheem-3 (Table 2). Furthermore, it is important to note that all the local lines of French bean were produced higher seed yield compared to BARI developed varieties which might be due to the higher 100 -seed weight of local lines.

Table 2. Yield contributing characters and seed yield of French bean at MLT site, Zakigonj during 2013-15 (Pooled of 2 years)

\begin{tabular}{lcccccc}
\hline Treatment & $\begin{array}{c}\text { Plant } \\
\text { height } \\
(\mathrm{cm})\end{array}$ & $\begin{array}{c}\text { Pods } \\
\text { plant }^{-1} \\
(\text { nos. })\end{array}$ & $\begin{array}{c}\text { Pod } \\
\text { length } \\
(\mathrm{cm})\end{array}$ & $\begin{array}{c}\text { Seeds } \\
\text { pod }^{-1} \\
\left(\text { nos. }^{-}\right.\end{array}$ & $\begin{array}{c}100 \text { seed } \\
\text { weight } \\
(\mathrm{g})\end{array}$ & $\begin{array}{c}\text { Seed } \\
\text { yield } \\
\left.\text { (tha }^{-1}\right)\end{array}$ \\
\hline BARI Jharsheem- & 41.77 & 10.20 & 13.34 & 5.57 & & \\
1 & & & & & 38.67 & 1.82 \\
BARI Jharsheem- & 43.83 & 10.10 & 12.39 & 5.30 & & \\
2 & & & & & 41.37 & 1.81 \\
BARI Jarsheem-3 & 46.19 & 11.05 & 12.44 & 5.30 & 46.55 & 1.58 \\
Local-1 & 41.47 & 9.87 & 13.42 & 5.04 & 67.00 & 2.79 \\
Local-2 & 43.49 & 12.37 & 13.74 & 4.87 & 69.80 & 3.21 \\
Local-3 & 42.38 & 12.74 & 13.62 & 4.47 & 80.82 & 3.37 \\
Local-4 & 43.37 & 9.53 & 13.35 & 4.40 & 79.00 & 3.12 \\
Local-5 & 42.69 & 9.93 & 14.15 & 4.81 & 81.45 & 3.48 \\
\hline CV $(\%)$ & 7.62 & 21.33 & 6.05 & 10.49 & 10.95 & 17.23 \\
\hline LSD $(0.05)$ & $\mathrm{NS}$ & 3.80 & 1.24 & 0.92 & 13.73 & 0.79 \\
\hline
\end{tabular}

\section{Location: MLT site, Moulvibazar}

At Moulvibazar, BARI developed varieties contributed maximum plant height $(55.30,54.92$ and $54.25 \mathrm{~cm})$ followed by Local-5 $(52.45 \mathrm{~cm})$. The shortest plant height $(45.61 \mathrm{~cm})$ was observed in Local-2. The maximum number of pods per plant was recorded in the var. BARI Jharsheem-2 (18.08) that was followed by BARI Jharsheem-1 (17.35) and BARI Jharsheem- 
Performance of French Bean (Phaseolus vulgaris L.) Genotypes in Sylhet Region of Bangladesh

3 (16.99) while the lowest value (8.36) in Local-5 (Table 3). The maximum pod length (14.20 $\mathrm{cm}$ ) was measured in the var. BARI Jharsheem-1, followed by lines Local-1, Local-3 and Local-5. The results are in agreements with the findings of Rashid and Hossain (2014), who reported that the longest pod $(14.89 \mathrm{~cm})$ was recorded with the maximum days after flowering in French bean. In case of seeds per pod, the higher value (5.87) was observed in BARI Jharsheem-1 that was statistically similar to the BARI Jharsheem-2 and the lowest (4.85) in Local-4. Most of the local French bean lines produced maximum 100 seed weight except Local-1. The maximum 100- seed weight of French bean was obtained in the line Local-2 $(57.50 \mathrm{~g})$ that was statistically similar with that of all local lines $(55.01$ to $55.23 \mathrm{~g})$. It is noted that the 100- seed weight of BARI developed French bean varieties was much lower than that of local lines. It might be due to smaller size seeds compared to local lines of bush bean. The lowest 100-seed weight $(24.63 \mathrm{~g})$ was gained in BARI Jharsheem-1. The maximum seed yield $\left(2.05\right.$ tha $\left.^{-1}\right)$ was recorded in line Local-5 that was statistically similar to all local lines; on the other hand, BARI developed French bean varieties produce lower yield ranged from 1.52 to $1.56 \mathrm{t} \mathrm{ha}^{-1}$. The local lines gave higher yield might be due to the bolder size with higher 100-seed weight. These results are in consensus with the findings of Singh et al. (2014) in French bean. Another point is that the bush bean varieties BARI Jhahrsheem-1 and BARI Jahrsheem-2 were released for vegetables purposes. The seed yields were varied across the location might be due to the local climatic condition along with adaptability of French bean.

Table 3. Yield contributing characters and seed yield of French bean at MLT site, Moulvibazar during 2013-15 (Pooled of 2 years)

\begin{tabular}{lcccccc}
\hline \multicolumn{1}{c}{ Treatment } & $\begin{array}{c}\text { Plant } \\
\text { height } \\
(\mathrm{cm})\end{array}$ & $\begin{array}{c}\text { Pods } \\
\text { plant }^{-1} \\
\text { (nos. })\end{array}$ & $\begin{array}{c}\text { Pod } \\
\text { length } \\
(\mathrm{cm})\end{array}$ & $\begin{array}{c}\text { Seeds } \\
\text { pod }^{-1} \\
(\text { nos. })\end{array}$ & $\begin{array}{c}100- \\
\text { seed } \\
\text { weight } \\
(\mathrm{g})\end{array}$ & $\begin{array}{c}\text { Seed yield } \\
\left.\text { (tha }^{-1}\right)\end{array}$ \\
\hline $\begin{array}{l}\text { BARI Jharsheem- } \\
1\end{array}$ & 54.92 & 17.35 & 14.20 & 5.87 & 24.63 & 1.56 \\
BARI Jharsheem- & 54.25 & 18.08 & 12.55 & 5.60 & 25.63 & 1.39 \\
2 & & & & & & \\
BARI Jharsheem- & 55.30 & 16.99 & 12.48 & 5.21 & 26.07 & 1.52 \\
3 & & & & & & \\
Local-1 & 49.40 & 11.89 & 13.81 & 5.49 & 40.00 & 1.91 \\
Local-2 & 45.61 & 11.19 & 13.61 & 5.25 & 57.50 & 1.95 \\
Local-3 & 48.64 & 10.74 & 13.73 & 4.87 & 55.20 & 1.99 \\
Local-4 & 47.90 & 8.55 & 12.70 & 4.85 & 55.01 & 1.98 \\
Local-5 & 52.45 & 8.36 & 13.79 & 5.54 & 55.23 & 2.05 \\
\hline CV $(\%)$ & 6.87 & 19.75 & 6.69 & 12.42 & 4.08 & 3.23 \\
\hline LSD $(0.05)$ & 5.51 & 3.98 & 1.40 & 0.80 & 1.61 & 0.22 \\
\hline
\end{tabular}

\section{Conclusion}

This study showed that French bean genotypes (Local-1, Local-2, Local-3, Local-4, and Local-5) significantly out yielded the varieties developed by BARI. The local lines of French bean are very much popular due to bold seeded and takes less time to boil are utilizing for making pulse curry in Sylhet. Therefore, it could be suggested to the breeder to collect the local materials of French bean and released as variety with management practices. Further research work may be undertaken on varietal development and cultural management 
Nazrul et al.

practice of local French bean accessions to maximize the seed yield and higher economic return for the farmers.

\section{Acknowledgement}

The authors would like to thank the bush bean growers for helping to collect bean germplasms to carry out this research and also acknowledged to the Metrological Departments of Sylhet and Moulvibazar districts of Bangladesh for providing the weather data.

\section{References}

Ali, M. and B. L. Kushwaha. 1987. Cultivation of rabi rajmash in plains. Indian Farm. 31(2): 2023.

Das, R., U. Thapa, S. Debnath, Y. A. Lyngdoh and D. Mallick. 2014. Evaluation of French bean (Phaseolus vulgaris L.) genotypes for seed production. J. Appl. Nat. Sci. 6(2): 594-598.

Dhanjal, R., O. Prakash and I. P. S. Ahlawat. 2001. Response of French bean (Phaseolus vulgaris L.) varieties to plant density and nitrogen application. Indian J. Agron. 46(2): 277-281.

Galvan, M. Z., B. Bornet, P. A. Balatti and M. Branchard. 2003. Inter simple sequence repeat (ISSR) markers as a tool for the assessment of both genetic diversity and gene pool origin in common bean (Phaseolus vulgaris L.). Euphytica. 132: 297-301.

Gomez, K. A. and A. A. Gomez. 1984. Statistical Procedures for Agricultural Research, 2nd Ed. John Wiley and Sons, New York. P. 194.

Mozumder, M. A., M. A. Rouf, M. S. Mollah and M. A. Rashid. 1996. Collection and evaluation of Bush bean germplasms. In: M. A. Rashid (ed.). Research Report on Vegetable Crops, HRC, RARS, Hathazari. Pp. 35-39.

Muthuramu, S., V. K. Paulpandi, S. Sakthivel, K. Ramakrishnan, R. Karthik. 2015. Assessing the Performance of French Bean (Phaseolus vulgaris $\mathrm{L}$ ) in District Virudhunagar of Tamilnadu. J. Krishi Vigyan. 3(2): 5-7.

Noor, F., F. Hossain and U. Ara. 2014. Screening of French bean (Phaseolus vulgaris L.) genotypes for high yield potential. Bangladesh J. Sci. Ind. Res. 49(4): 227-232.

Rashid, A. S. M. H and M. M. Hossain. 2014. Yield and Quality of Green Pod Production of Bush Bean (Phaseolus vulgaris L.) As Influenced by Harvesting Time. Am.

Eurasian J. Agric. Environ. Sci. 14(11): 1221-1227.

Roy, S. K., M. A. Karim, A. K. M. A. Islam, M. N. Bari, M. A. K. Mian and H. Tetsushi. 2006. Relationship between yield and its component characters of bush bean (Phaseolus vulgaris L.). South Pac. Stud. 27(1): 13-23.

Shivakumar, B. G., C. S. Saraf and R. R. Path. 1996. Performance of winter French bean as influenced by varieties, spacing and time of sowing. Ann. Agric. Res. 17(4): 407-410.

Singh, D. P., A. L. Rajat and S. K. Singh. 1996. Response of French bean (Phaseolus vulgaris L.) to spacing and nitrogen levels. Indian J. Agron. 41(4): 608-610.

Singh, V., A. K. Singh, H. K. and B. V. Rajkumar. 2014. Performance of French bean genotypes (Phaseolus vulgaris L.) for seed yield and related traits under Varanasi conditions. New Agriculturist 25(2): 251- 254.

Smithson, J. B., O. T. Edge and K. E. Giller. 1993. Diagnosis and correction of soil nutrient problems of common bean (Phaseolus vulgaris) in the Usambara mountains of Tanzania. J. Agric. Sci. Cambridge. 120: 233-240. 